\title{
Bacillus oceanisediminis sp. nov., isolated from marine sediment
}

\author{
Jianli Zhang, ${ }^{1}$ Jiewei Wang, ${ }^{1}$ Caiyuan Fang, ${ }^{1}$ Fei Song, ${ }^{1}$ Yuhua Xin, ${ }^{2}$ \\ Lei $\mathrm{Qu}^{1}$ and Kai Ding ${ }^{1}$ \\ ${ }^{1}$ School of Life Science and Technology, Beijing Institute of Technology, Beijing 100081, PR China \\ ${ }^{2}$ China General Microbiological Culture Collection Center, Institute of Microbiology, Chinese \\ Academy of Sciences, Beijing 100101, PR China
}

Correspondence

Jianli Zhang

zhangjianli@bit.edu.cn
The application of chemotaxonomic, numerical phenetic and molecular systematic methods has led to an improved description and a division of the genus Bacillus. Some species have been reclassified in novel genera or transferred to other genera (Ash et al., 1993; Stackebrandt \& Liesack, 1993; Shida et al., 1996; Wainø et al., 1999; Nazina et al., 2001; Yoon et al., 2001; Albert et al., 2007; Zhou et al., 2009). Many of these reclassifications are well supported by relatively conserved phenotypic traits such as the quinone system, peptidoglycan composition and polar lipid and cellular fatty acid profiles (Albert et al., 2007). Falsibacillus is a newly described genus, which currently comprises a single species, Falsibacillus pallidus comb. nov., and is represented by the type strain, $\mathrm{CW} 7^{\mathrm{T}}$. The taxon $F$. pallidus comb. nov. is linked to the illegitimately named taxon Bacillus pallidus Zhou et al. 2008 and the creation of the genus Falsibacillus was primarily based on significant chemotaxonomic differences in comparison with the type species of the genus Bacillus, Bacillus subtilis (Zhou et al., 2008, 2009). The genus Bacillus currently encompasses more than 150 species with validly published names and contains at least six phylogenetically distinct groups on the basis of molecular analyses of 16S rRNA gene sequences

The GenBank/EMBL/DDBJ accession number for the 16S rRNA gene sequence of strain $\mathrm{H}^{\top}{ }^{\top}$ is $\mathrm{GQ} 292772$.

A comparison of the fatty acid profiles of strain $\mathrm{H}_{2}^{\top}$ and its closest phylogenetic neighbours is available with the online version of this paper.
(Ash et al., 1991; Nielsen et al., 1994; Schlesner et al., 2001; Yoon et al., 2004; Carrasco et al., 2007). Members of the genus Bacillus have been isolated from a wide variety of aquatic and terrestrial environments. A Gram-stain-positive bacterium, strain $\mathrm{H} 2^{\mathrm{T}}$, was isolated during an ecological survey of marine organisms in China and found to have morphological properties consistent with the genus Bacillus.

Strain $\mathrm{H} 2^{\mathrm{T}}$ was isolated from a marine sediment collected at a depth of $823 \mathrm{~m}$ in the South Sea, China. A standard dilution-plating technique was used to isolate the strain on marine agar 2216 (MA; Difco) at $37{ }^{\circ} \mathrm{C}$ for 3 days. Strain $\mathrm{H} 2^{\mathrm{T}}$ was maintained on LB agar ( $10 \mathrm{~g}$ tryptone, $5 \mathrm{~g}$ yeast extract, $10 \mathrm{~g} \mathrm{NaCl}, 1 \mathrm{l}$ distilled water; $\mathrm{pH} \mathrm{7.0)}$ at $4{ }^{\circ} \mathrm{C}$ and stored in $20 \%(\mathrm{v} / \mathrm{v})$ glycerol suspensions at $-20{ }^{\circ} \mathrm{C}$.

To characterize strain $\mathrm{H}_{2}{ }^{\mathrm{T}}$ phenotypically, standard phenotypic tests were performed according to procedures described elsewhere (Gordon et al., 1973, 1977; Smibert \& Krieg, 1994; Zhang et al., 2008, 2009). Cellular morphology was examined by light microscopy (BH-2; Olympus). Gram staining was performed as described by Gerhardt et al. (1981). The morphology, size and pigmentation of colonies were observed on LB agar, MA and nutrient agar after 1 day at $37^{\circ} \mathrm{C}$. Catalase activity was determined on freshly growing colonies using $3 \%(\mathrm{v} / \mathrm{v})$ hydrogen peroxide solution. The oxidase reaction was performed on filter paper moistened with a $1 \%(\mathrm{w} / \mathrm{v})$ aqueous solution of $N, N, N^{\prime}, N^{\prime}$-tetramethyl-p-phenylenediamine. Growth under 
various $\mathrm{pH}$, temperature and sodium chloride regimes was determined on LB agar after incubation for up to 7 days. Acid production from carbohydrates was determined using methods described by Gordon et al. (1974) and utilization of sole carbon sources was determined according to Gordon \& Mihm (1957). Resistance to antibiotics was examined using impregnated filter-paper discs (Goodfellow \& Orchard, 1974) on LB agar and incubation at $37^{\circ} \mathrm{C}$ for up to 7 days. Resistance to lysozyme was determined by the method of Gordon et al. (1973). Strain $\mathrm{H}^{2}{ }^{\mathrm{T}}$ was Gram-stain-positive and aerobic. The cells were spore-forming rods $(0.6-0.8$ by 2.0-3.0 $\mu \mathrm{m}$ ). After 1 day at $37{ }^{\circ} \mathrm{C}$ on LB agar, colonies were circular, creamy white and $1-3 \mathrm{~mm}$ in diameter. Strain $\mathrm{H} 2^{\mathrm{T}}$ grew at $4-45^{\circ} \mathrm{C}$ (optimum $37{ }^{\circ} \mathrm{C}$ ) and $\mathrm{pH}$ 6-10 (optimum $\mathrm{pH}$ 7.0). A range of phenotypic properties separated strain $\mathrm{H} 2^{\mathrm{T}}$ from its closest phylogenetic neighbours (Table 1). In particular, the isolate could be differentiated from Bacillus firmus ATCC $14575^{\mathrm{T}}$ in that it was positive for utilization of D-galactose, inulin, myo-inositol, lactose, D-sorbitol and xylitol. Additional phenotypic properties are presented in the species description and Table 1.
Biomass for most of the chemotaxonomic and molecular systematic studies was prepared as described by Zhang et al. (2002), with the modification of using shake flasks of LB broth. Preparation of the cell wall and determination of the peptidoglycan composition were performed using the methods described by Schleifer (1985), with the modification that cellulose sheets instead of paper were used for TLC. Isoprenoid quinones were extracted and purified according to Collins et al. (1987) and purified menaquinones were determined by reversed-phase HPLC (Wu et al., 1989). Polar lipids were examined by twodimensional TLC and identified using the method of Minnikin et al. (1984). The cellular fatty acid profile was determined for cells cultured on tryptic soy broth agar at $28{ }^{\circ} \mathrm{C}$ for $24 \mathrm{~h}$. Cells were saponified and the cellular fatty acids were extracted, purified, methylated and quantified by GC using the standard Microbial Identification System (MIDI; Sasser, 1990; Kämpfer \& Kroppenstedt, 1996). The $\mathrm{G}+\mathrm{C}$ content of the DNA was determined using the thermal denaturation method (Marmur \& Doty, 1962) with Escherichia coli AS 1.365 as a reference.

Table 1. Comparison of properties of strain $\mathrm{H}_{2}^{\top}$ with the three most closely related type strains of species in the genus Bacillus and the type strain of Falsibacillus pallidus

Strains: 1, Bacillus oceanisediminis sp. nov. $\mathrm{H}^{\mathrm{T}}$; 2, B. firmus ATCC $14575^{\mathrm{T}} ; 3$, B. infantis SMC 4352-1 ${ }^{\mathrm{T}}$; 4, B. nealsonii ATCC BAA-519 ${ }^{\mathrm{T}}$; 5, F. pallidus CW $7^{\mathrm{T}}$. Data were taken from this study and Gordon et al. (1977), Venkateswaran et al. (2003), Ko et al. (2006) and Zhou et al. (2009). + , Positive; w, weakly positive; v, variable; -, negative; ND, no data available.

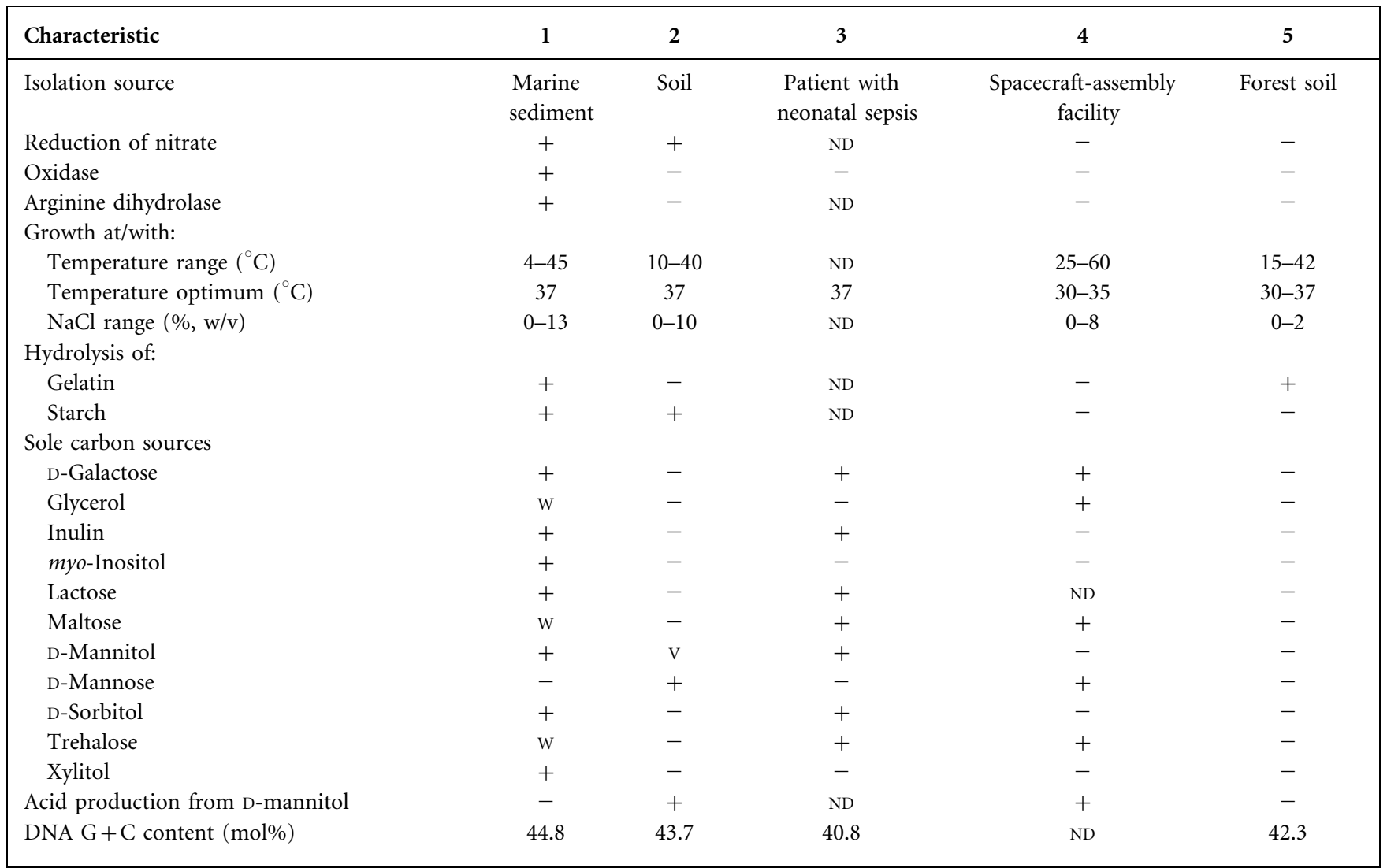


Analysis of the cell-wall peptidoglycan showed that strain $\mathrm{H} 2^{\mathrm{T}}$ possessed the $\mathrm{A} 1 \gamma$ type, with meso-diaminopimelic acid as the diagnostic diamino acid, which is in common with a large majority of members of the genus Bacillus (Priest et al., 1988). Strain $\mathrm{H}_{2}^{\mathrm{T}}$ contained $\mathrm{MK}-7$ as the major menaquinone. The polar lipids detected were diphosphatidylglycerol, phosphatidylglycerol, phosphatidylethanolamine and an unknown aminophospholipid. The cellular fatty acid profile of strain $\mathrm{H}_{2}{ }^{\mathrm{T}}$ contained iso$\mathrm{C}_{15: 0}(35.65 \%), \mathrm{C}_{16: 1} \omega 7 c$ alcohol $(9.97 \%)$, iso- $\mathrm{C}_{14: 0}$ $(9.71 \%)$, anteiso- $\mathrm{C}_{15: 0}(9.61 \%)$, iso- $\mathrm{C}_{16: 0}(9.21 \%)$ and summed feature 4 (iso- $\mathrm{C}_{17: 1}$ I and/or anteiso- $\mathrm{C}_{17: 1}$ $\mathrm{B} ; 6.73 \%)$ as the major fatty acids (>5\%) (Supplementary Table S1, available in IJSEM Online). These isoand anteiso-branched fatty acids of the 14-17-carbon series are typical of those found in the cell membranes of members of the genus Bacillus (Kämpfer, 1994; Albert et al., 2005). Thus, these chemotaxonomic features of strain $\mathrm{H} 2^{\mathrm{T}}$ were typical of those for the genus Bacillus (Priest et al., 1988; Heyrman et al., 2004; Albert et al., 2005, 2007; Wieser et al., 2005; Lim et al., 2006a, b; Xue et al., 2008). In addition, the DNA $\mathrm{G}+\mathrm{C}$ content of strain $\mathrm{H}_{2}{ }^{\mathrm{T}}$ was $44.8 \mathrm{~mol} \%$, which is within the range for the genus Bacillus (Nielsen et al., 1995; Priest et al., 1988).

Chromosomal DNA preparation from strain $\mathrm{H}^{\mathrm{T}}$, PCRmediated amplification of the 16S rRNA gene and purification of the amplification product were carried out according to Rainey et al. (1996) and the amplification product was sequenced directly using the method of $\mathrm{Lu}$ et al. (2001). Nucleotide sequences were sequenced automatically using an Applied Biosystems DNA sequencer (model 377) and software provided by the manufacturer. The resultant $16 \mathrm{~S}$ rRNA gene sequence was compared with those available from the GenBank database using the BLAST program to determine an approximate phylogenetic affiliation for strain $\mathrm{H} 2^{\mathrm{T}}$. Multiple alignment with closely related sequences was performed using CLUSTAL X version 1.8 (Thompson et al., 1997). Phylogenetic trees were reconstructed using the neighbour-joining (Saitou \& Nei, 1987), minimum-evolution and maximum-parsimony algorithms in MEGA version 3.1 (Kumar et al., 2004). Evolutionary distance matrices were generated according to Kimura (1980). Topologies of the resultant unrooted trees were evaluated by bootstrap analysis (Felsenstein, 1985) using 1000 resamplings of the neighbour-joining dataset.

An almost-complete 16S rRNA gene sequence (1393 nt) was obtained for strain $\mathrm{H}_{2}{ }^{\mathrm{T}}$. Phylogenetic analysis showed that the isolate belonged in the phyletic group classically defined as the genus Bacillus. The type strains of species of the genus Bacillus with the greatest pairwise similarity to strain $\mathrm{H}_{2}^{\mathrm{T}}$ were B. firmus IAM $12464^{\mathrm{T}}$ (98.5\% $16 \mathrm{~S}$ rRNA gene sequence similarity), $B$. infantis SMC $4352-1^{\mathrm{T}}$ $(98.3 \%)$ and $B$. nealsonii $\mathrm{FO}-92^{\mathrm{T}}(97.7 \%)$. The sequence similarities between strain $\mathrm{H}_{2}{ }^{\mathrm{T}}$ and other members of the genus Bacillus were below $97.0 \%$. The initial alignment included 16S rRNA gene sequences from members of nearly all of the species of the genus Bacillus with validly published names. Of these, 25 sequences were found to have a close relationship with strain $\mathrm{H} 2^{\mathrm{T}}$ and were selected for further analysis. It is apparent from the neighbourjoining phylogenetic tree (Fig. 1) that strain $\mathrm{H} 2^{\mathrm{T}}$ forms a coherent cluster with B. firmus IAM $12464^{\mathrm{T}}$ and B. infantis SMC $4352-1^{\mathrm{T}}$ within the genus Bacillus and is distantly related to other members of the genus. The same results were obtained with the other methods of phylogenetic reconstruction used in the study, minimum evolution and maximum parsimony (data not shown).

There are widely accepted criteria for delineating species in current bacteriology, stating that strains with $<70 \%$ DNA-DNA relatedness or with $<97 \% 16 \mathrm{~S}$ rRNA gene sequence similarity are considered to represent different species (Wayne et al., 1987; Stackebrandt \& Goebel, 1994; Stackebrandt et al., 2002). Many members of the genus Bacillus with $>98.5 \% 16 \mathrm{~S}$ rRNA gene sequence similarity are considered to belong to different species. For example, the 16S rRNA gene sequences of the type strains of Bacillus bataviensis, B. soli, B. drentensis, $B$. novalis and B. vireti show $98.7-99.6 \%$ pairwise similarity (Ko et al., 2006). DNA-DNA relatedness provides a reliable way of distinguishing between representatives of species that share high $16 \mathrm{~S}$ rRNA gene sequence similarity (Goodfellow et al., 1998). In the present study, DNA-DNA relatedness studies were carried out between the isolate and its closest phylogenetic neighbours, B. firmus ATCC $14575^{\mathrm{T}}, B$. infantis SMC $4352-1^{\mathrm{T}}$ and B. nealsonii ATCC BAA-519 ${ }^{\mathrm{T}}$, using the liquid renaturation method (De Ley et al., 1970; Huß et al., 1983; Jahnke, 1992) using a model Lambda 35 UV/VIS spectrometer equipped with a temperature program controller (Perkin-Elmer) and the results were expressed as the mean of three determinations. Strain $\mathrm{H} 2^{\mathrm{T}}$ showed low levels of DNA-DNA relatedness with $B$. firmus ATCC $14575^{\mathrm{T}}(27.5 \%)$, B. infantis SMC $4352-1^{\mathrm{T}}$ $(23.1 \%)$ and B. nealsonii ATCC BAA-519 ${ }^{\mathrm{T}}(20.7 \%)$; all of these values are well below the $70 \%$ cut-off point.

Although strain $\mathrm{H}_{2}{ }^{\mathrm{T}}$ showed a higher $16 \mathrm{~S}$ rRNA gene sequence similarity with $F$. pallidus $\mathrm{CW} 7^{\mathrm{T}}$ (97\%) than with the type strain of the type species of the genus Bacillus, B. subtilis NCDO $1769^{\mathrm{T}}(96 \%)$, the isolate did not belong to the genus Falsibacillus. Chemotaxonomic data showed some significant differences in comparison with F. pallidus CW $7^{\mathrm{T}}$ (Supplementary Table S1). Polar lipid profiles have proved to be a most useful tool for the classification and determination of members of the family Bacillaceae in recent years (Zhou et al., 2009). The polar lipid profile of $B$. subtilis has been shown to be characteristic of the genus Bacillus and should form part of the genus description (Kämpfer et al., 2006). The polar lipid profile of B. subtilis comprises diphosphatidylglycerol, phosphatidylglycerol, phosphatidylethanolamine, an unknown aminophospholipid and $\beta$-gentiobiosyldiacylglycerol (Kämpfer et al., 2006; Albert et al., 2007), while the polar lipids of F. pallidus comprise diphosphatidylglycerol, phosphatidylglycerol, phosphatidylethanolamine, two aminophosphoglycolipids, five unknown 


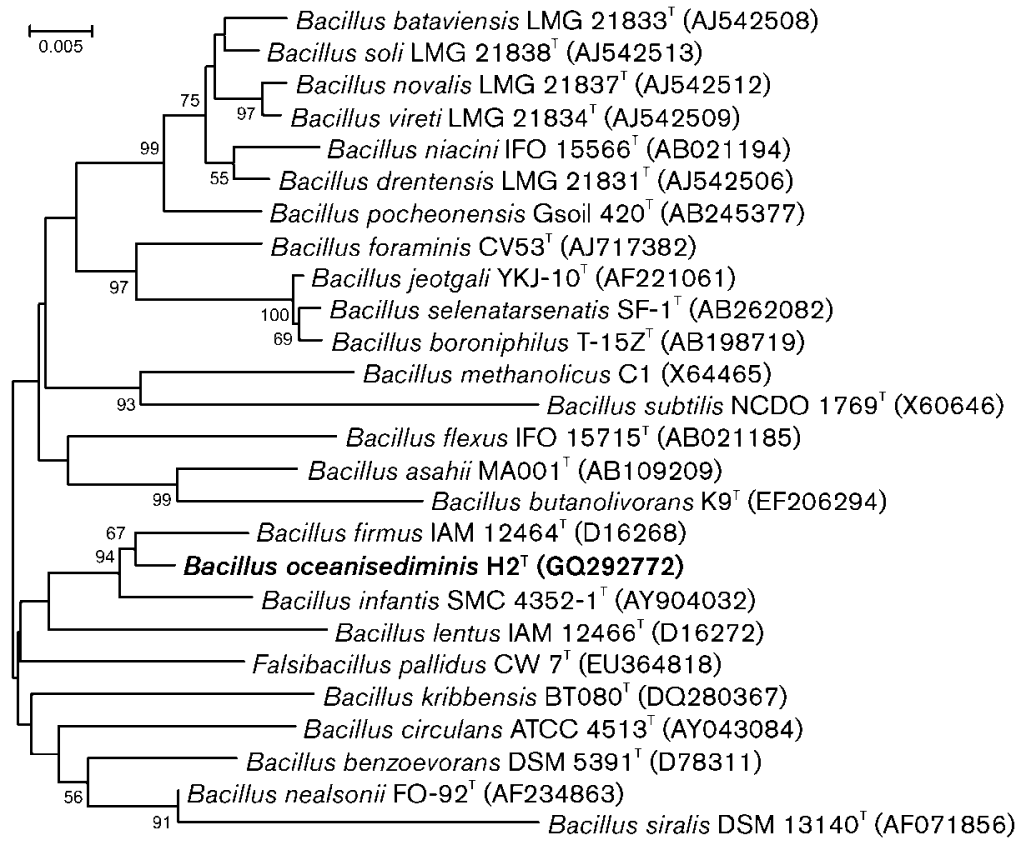

Fig. 1. Neighbour-joining tree, based on nearly complete 16S rRNA gene sequences, showing the relationships between strain $\mathrm{H}_{2}{ }^{\top}$ and related type strains in the genus Bacillus. Bootstrap values $(>50 \%)$ based on 1000 resampled datasets are shown at branch nodes. Bar, 0.005 substitutions per nucleotide position. phospholipids, two phosphoglycolipids and one glycolipid (Zhou et al., 2009). The polar lipid profile of strain $\mathrm{H}_{2}^{\mathrm{T}}$ was similar to those for the genus Bacillus. The significant differences in the cellular fatty acid profile and phenotypic properties (Table 1 and Supplementary Table S1) can be used to distinguish strain $\mathrm{H}^{\mathrm{T}}$ from $F$. pallidus $\mathrm{CW} 7^{\mathrm{T}}$ and, therefore, it is concluded that the isolate should be placed in the genus Bacillus.

On the basis of the taxonomic data described above, strain $\mathrm{H} 2^{\mathrm{T}}$ represents a novel species of the genus Bacillus, for which the name Bacillus oceanisediminis sp. nov. is proposed.

\section{Description of Bacillus oceanisediminis sp. nov.}

Bacillus oceanisediminis (o.ce.a.ni.se.di'mi.nis. L. n. oceanus ocean; L. n. sedimen -inis sediment; N.L. gen. n. oceanisediminis of/from sediment of the ocean).

Cells are $0.6-0.8 \mu \mathrm{m}$ in width and $2-3 \mu \mathrm{m}$ in length, Gramstain-positive, aerobic, round-ended rods that occur singly or in pairs and occasionally in short chains. Ellipsoidal endospores are formed subterminally, paracentrally or centrally. After 1 day at $37{ }^{\circ} \mathrm{C}$ on LB agar, colonies are creamy white, slightly convex in the centre, smooth, round and $1-3 \mathrm{~mm}$ in diameter; edges are usually irregular with pointed projections that may spread and become rhizoid in old cultures. Diffusible pigments are not formed. Grows at $4-45{ }^{\circ} \mathrm{C}$ (optimum $37{ }^{\circ} \mathrm{C}$ ), at $\mathrm{pH}$ 6-10 (optimum pH 7.0) and with $0-13 \%(\mathrm{w} / \mathrm{v}) \mathrm{NaCl}$. Positive for catalase, oxidase, $\beta$-galactosidase and arginine dihydrolase, but negative for lipase, phenylalanine deaminase and urease. Nitrate is reduced. Indole and methyl red tests are positive, but
Voges-Proskauer and egg-yolk reactions are negative. Hydrogen sulphide is not produced. Adenine, casein, gelatin, starch and tyrosine (weak) are hydrolysed; aesculin and arbutin are not hydrolysed. Acid is formed from Dglucose, inulin, glycogen, raffinose and sucrose but not from L-arabinose, cellobiose, D-fructose, D-galactose, glycerol, myo-inositol, lactose, maltose, D-mannitol, melezitose, melibiose, $\alpha$-L-rhamnose, D-sorbitol, trehalose, D-xylitol or D-xylose. As sole carbon and energy sources, utilizes cellobiose, meso-erythritol, D-glucose, glycogen, melezitose, raffinose, $\alpha$-L-rhamnose, sucrose, acetate, fumarate, lactic acid, malate, pyruvic acid, sorbic acid, succinate and tartrate (weak), but not L-arabinose, D-fructose, melibiose, D-ribose, L-sorbose, D-xylose, benzoate, citrate, malonate, propionate or oxalate. Resistant to ( $\mu \mathrm{g}$ per disc unless otherwise stated) aztreonam (30), but susceptible to lysozyme $(0.005 \%$, w/v), amikacin (30), amoxicillin plus clavulanic acid (10), ampicillin (10), cefotaxime (30), chloramphenicol (30), ciprofloxacin (5), clindamycin hydrochloride (2), erythromycin (15), gentamicin sulphate (10), kanamycin sulphate (30), mezlocillin (75), ofloxacin (5), penicillin G (10 U), rifampicin (5), streptomycin sulphate (10), tetracycline hydrochloride (30) and tobramycin sulphate (10). Additional phenotypic properties are shown in Table 1. Chemotaxonomic properties are typical of the genus Bacillus: the cell-wall peptidoglycan contains meso-diaminopimelic acid, the major isoprenoid quinone type is MK-7 and the polar lipids are diphosphatidylglycerol, phosphatidylglycerol, phosphatidylethanolamine and an unknown aminophospholipid. The fatty acid profile $(>2 \%)$ is composed of iso- $\mathrm{C}_{15: 0}, \mathrm{C}_{16: 1} \omega 7 c$ alcohol, iso- $\mathrm{C}_{14: 0}$, anteiso- $\mathrm{C}_{15: 0}$, iso- $\mathrm{C}_{16: 0}$, summed feature 4 (iso- $\mathrm{C}_{17: 1} \mathrm{I}$ and/or anteiso- $\left.\mathrm{C}_{17: 1} \mathrm{~B}\right)$, iso- $\mathrm{C}_{16: 1} \mathrm{H}$, iso- $\mathrm{C}_{17: 1} \omega 10 c$, anteiso- $\mathrm{C}_{17: 0}$, iso- $\mathrm{C}_{17: 0}$ and $\mathrm{C}_{16: 1} \omega 11 c$. The genomic DNA G $+\mathrm{C}$ content of the type strain is $44.8 \mathrm{~mol} \%$. 
The type strain, $\mathrm{H} 2^{\mathrm{T}}\left(=\mathrm{CGMCC} 1.10115^{\mathrm{T}}=\mathrm{JCM} 16506^{\mathrm{T}}\right)$, was isolated from a sediment sample from the South Sea, China.

\section{Acknowledgements}

This research was supported by the National Natural Science Foundation of China (NSFC, grant number 30970009), and by the University Basic Fund of Beijing Institute of Technology of China (grant number 20081642008).

\section{References}

Albert, R. A., Archambault, J., Rosselló-Mora, R., Tindall, B. J. \& Matheny, M. (2005). Bacillus acidicola sp. nov., a novel mesophilic, acidophilic species isolated from acidic Sphagnum peat bogs in Wisconsin. Int J Syst Evol Microbiol 55, 2125-2130.

Albert, R. A., Archambault, J., Lempa, M., Hurst, B., Richardson, C., Gruenloh, S., Duran, M., Worliczek, H. L., Huber, B. E. \& other authors (2007). Proposal of Viridibacillus gen. nov. and reclassification of Bacillus arvi, Bacillus arenosi and Bacillus neidei as Viridibacillus arvi gen. nov., comb. nov., Viridibacillus arenosi comb. nov. and Viridibacillus neidei comb. nov. Int J Syst Evol Microbiol 57, 2729-2737.

Ash, C., Farrow, J. A. E., Wallbanks, S. \& Collins, M. D. (1991). Phylogenetic heterogeneity of the genus Bacillus revealed by comparative analysis of small-subunit-ribosomal RNA sequences. Lett Appl Microbiol 13, 202-206.

Ash, C., Priest, F. G. \& Collins, M. D. (1993). Molecular identification of rRNA group 3 bacilli (Ash, Farrow, Wallbanks and Collins) using a PCR probe test. Proposal for the creation of a new genus Paenibacillus. Antonie van Leeuwenhoek 64, 253-260.

Carrasco, I. J., Márquez, M. C., Xue, Y., Ma, Y., Cowan, D. A., Jones, B. E., Grant, W. D. \& Ventosa, A. (2007). Bacillus chagannorensis sp. nov., a moderate halophile from a soda lake in Inner Mongolia, China. Int J Syst Evol Microbiol 57, 2084-2088.

Collins, M. D., Howarth, O. W., Grund, E. \& Kroppenstedt, R. M. (1987). Isolation and structural determination of new members of the vitamin $\mathrm{K}_{2}$ series in Nocardia brasiliensis. FEMS Microbiol Lett 41, 3539.

De Ley, J., Cattoir, H. \& Reynaerts, A. (1970). The quantitative measurements of DNA hybridization from renaturation rates. Eur $J$ Biochem 12, 133-142.

Felsenstein, J. (1985). Confidence limits on phylogenies: an approach using the bootstrap. Evolution 39, 783-791.

Gerhardt, P., Murray, R. G. E., Costilow, R. N., Nester, E. W., Wood, W. A., Krieg, N. R. \& Phillips, G. B. (editors) (1981). Manual of Methods for General Bacteriology. Washington, DC: American Society for Microbiology.

Goodfellow, M. \& Orchard, V. A. (1974). Antibiotic sensitivity of some nocardioform bacteria and its value as a criterion for taxonomy. J Gen Microbiol 83, 375-387.

Goodfellow, M., Stainsby, F. M., Davenport, R., Chun, J. \& Curtis, T. (1998). Activated sludge foaming: the true extent of actinomycete diversity. Water Sci Technol 37, 511-519.

Gordon, R. E. \& Mihm, J. M. (1957). A comparative study of some strains received as nocardiae. J Bacteriol 73, 15-27.

Gordon, R. E., Haynes, W. C. \& Pang, C. H.-N. (1973). The Genus Bacillus. US Department of Agriculture Handbook no. 427. Washington, DC: Agricultural Research Service.
Gordon, R. E., Barnett, D. A., Handerhan, J. E. \& Pang, C. H.-N. (1974). Nocardia coeliaca, Nocardia autotrophica, and the nocardin strain. Int J Syst Bacteriol 24, 54-63.

Gordon, R. E., Hyde, J. L. \& Moore, J. A., Jr (1977). Bacillus firmusBacillus lentus: a series or one species? Int J Syst Bacteriol 27, 256262.

Heyrman, J., Vanparys, B., Logan, N. A., Balcaen, A., Rodriguez-Diaz, M., Felske, A. \& De Vos, P. (2004). Bacillus novalis sp. nov., Bacillus vireti sp. nov., Bacillus soli sp. nov., Bacillus botaviensis sp. nov. and Bacillus drentensis sp. nov., from the Drentse A grasslands. Int J Syst Evol Microbiol 54, 47-57.

Huß, V. A. R., Festl, H. \& Schleifer, K. H. (1983). Studies on the spectrophotometric determination of DNA hybridization from renaturation rates. Syst Appl Microbiol 4, 184-192.

Jahnke, K. D. (1992). BASIC computer program for evaluation of spectroscopic DNA renaturation data from Gilford System 2600 spectrophotometer on a PC/XT/AT type personal computer. J Microbiol Methods 15, 61-73.

Kämpfer, P. (1994). Limits and possibilities of total fatty acid analysis for classification and identification of Bacillus species. Syst Appl Microbiol 17, 86-98.

Kämpfer, P. \& Kroppenstedt, R. M. (1996). Numerical analysis of fatty acid patterns of coryneform bacteria and related taxa. Can $J$ Microbiol 42, 989-1005.

Kämpfer, P., Rosselló-Mora, R., Falsen, E., Busse, H.-J. \& Tindall, B. J. (2006). Cohnella thermotolerans gen. nov., sp. nov. and classification of 'Paenibacillus hongkongensis' as Cohnella hongkongensis sp. nov. Int J Syst Evol Microbiol 56, 781-786.

Kimura, M. (1980). A simple method for estimating evolutionary rates of base substitutions through comparative studies of nucleotide sequences. J Mol Evol 16, 111-120.

Ko, K. S., Oh, W. S., Lee, M. Y., Lee, J. H., Lee, H., Peck, K. R., Lee, N. Y. \& Song, J.-H. (2006). Bacillus infantis sp. nov. and Bacillus idriensis sp. nov., isolated from a patient with neonatal sepsis. Int $J$ Syst Evol Microbiol 56, 2541-2544.

Kumar, S., Tamura, K. \& Nei, M. (2004). MEGA3: integrated software for molecular evolutionary genetics analysis and sequence alignment. Brief Bioinform 5, 150-163.

Lim, J.-M., Jeon, C. O. \& Kim, C.-J. (2006a). Bacillus taeanensis sp. nov., a halophilic Gram-positive bacterium from a solar saltern in Korea. Int J Syst Evol Microbiol 56, 2903-2908.

Lim, J.-M., Jeon, C. O., Lee, S.-M., Lee, J.-C., Xu, L.-H., Jiang, C.-L. \& Kim, C.-J. (2006b). Bacillus salarius sp. nov., a halophilic sporeforming bacterium isolated from a salt lake in China. Int J Syst Evol Microbiol 56, 373-377.

Lu, Z., Liu, Z., Wang, L., Zhang, Y., Qi, W. \& Goodfellow, M. (2001). Saccharopolyspora flava sp. nov. and Saccharopolyspora thermophila sp. nov., novel actinomycetes from soil. Int J Syst Evol Microbiol 51, 319-325.

Marmur, J. \& Doty, P. (1962). Determination of base composition of deoxyribonucleic acid from its denaturation temperature. J Mol Biol 5, 109-118.

Minnikin, D. E., O'Donnell, A. G., Goodfellow, M., Alderson, G., Athalye, M., Schaal, A. \& Parlett, J. H. (1984). An integrated procedure for the extraction of bacterial isoprenoid quinones and polar lipids. J Microbiol Methods 2, 233-241.

Nazina, T. N., Tourova, T. P., Poltaraus, A. B., Novikova, E. V., Grigoryan, A. A., Ivanova, A. E., Lysenko, A. M., Petrunyaka, V. V., Osipov, G. A. \& other authors (2001). Taxonomic study of aerobic thermophilic bacilli: descriptions of Geobacillus subterraneus gen. nov., sp. nov. and Geobacillus uzenensis sp. nov. from petroleum reservoirs and transfer of Bacillus stearothermophilus, Bacillus 
thermocatenulatus, Bacillus thermoleovorans, Bacillus kaustophilus, Bacillus thermoglucosidasius and Bacillus thermodenitrificans to Geobacillus as the new combinations G. stearothermophilus, $G$. thermocatenulatus, G. thermoleovorans, G. kaustophilus, G. thermoglucosidasius and G. thermodenitrificans. Int J Syst Evol Microbiol 51, 433-446.

Nielsen, P., Rainey, F. A., Outtrup, H., Priest, F. G. \& Fritze, D. (1994). Comparative $16 \mathrm{~S}$ rDNA sequence analysis of some alkaliphilic bacilli and the establishment of a sixth rRNA group within the genus Bacillus. FEMS Microbiol Lett 117, 61-66.

Nielsen, P., Fritze, D. \& Priest, F. G. (1995). Phenetic diversity of alkaliphilic Bacillus strains: proposal for nine new species. Microbiology 141, 1745-1761.

Priest, F. G., Goodfellow, M. \& Todd, C. (1988). A numerical classification of the genus Bacillus. J Gen Microbiol 134, 1847-1882.

Rainey, F. A., Ward-Rainey, N., Kroppenstedt, R. M. \& Stackebrandt, E. (1996). The genus Nocardiopsis represents a phylogenetically coherent taxon and a distinct actinomycete lineage: proposal of Nocardiopsiaceae fam. nov. Int J Syst Bacteriol 46, 1088-1092.

Saitou, N. \& Nei, M. (1987). The neighbor-joining method: a new method for reconstructing phylogenetic trees. Mol Biol Evol 4, 406425.

Sasser, M. (1990). Identification of bacteria by gas chromatography of cellular fatty acids, MIDI Technical Note 101. Newark, DE: MIDI Inc.

Schleifer, K. H. (1985). Analysis of the chemical composition and primary structure of murein. Methods Microbiol 18, 123-156.

Schlesner, H., Lawson, P. A., Collins, M. D., Weiss, N., Wehmeyer, U., Völker, H. \& Thomm, M. (2001). Filobacillus milensis gen. nov., sp. nov., a new halophilic spore-forming bacterium with Orn-D-Glu-type peptidoglycan. Int J Syst Evol Microbiol 51, 425-431.

Shida, O., Takagi, H., Kadowaki, K. \& Komagata, K. (1996). Proposal for two new genera, Brevibacillus gen. nov. and Aneurinibacillus gen. nov. Int J Syst Bacteriol 46, 939-946.

Smibert, R. M. \& Krieg, N. R. (1994). Phenotypic characterization. In Methods for General and Molecular Bacteriology, pp. 607-654. Edited by P. Gerhardt, R. G. E. Murray, W. A. Wood \& N. R. Krieg. Washington, DC: American Society for Microbiology.

Stackebrandt, E. \& Goebel, B. M. (1994). Taxonomic note: a place for DNA-DNA reassociation and $16 \mathrm{~S}$ rRNA sequence analysis in the present species definition in bacteriology. Int J Syst Bacteriol 44, 846849.

Stackebrandt, E. \& Liesack, W. (1993). Nucleic acids and classification. In Handbook of New Bacterial Systematics, pp. 152-189. Edited by M. Goodfellow \& A. G. O’Donnell. London: Academic Press.

Stackebrandt, E., Fredericksen, W., Garrity, G. M., Grimont, P. A. D., Kämpfer, P., Maiden, M. C. J., Nesme, X., Rosselló-Mora, R., Swings, J. $\&$ other authors (2002). Report of the ad hoc committee for the reevaluation of the species definition in bacteriology. Int J Syst Evol Microbiol 52, 1043-1047.

Thompson, J. D., Gibson, T. J., Plewniak, F., Jeanmougin, F. \& Higgins, D. G. (1997). The CLUSTAL_X windows interface: flexible strategies for multiple sequence alignment aided by quality analysis tools. Nucleic Acids Res 25, 4876-4882.

Venkateswaran, K., Kempf, M., Chen, F., Satomi, M., Nicholson, W. \& Kern, R. (2003). Bacillus nealsonii sp. nov., isolated from a spacecraftassembly facility, whose spores are $\gamma$-radiation resistant. Int J Syst Evol Microbiol 53, 165-172.

Wainø, M., Tindall, B. J., Schumann, P. \& Ingvorsen, K. (1999). Gracilibacillus gen. nov., with description of Gracilibacillus halotolerans gen. nov., sp. nov.; transfer of Bacillus dipsosauri to Gracilibacillus dipsosauri comb. nov., and Bacillus salexigens to the genus Salibacillus gen. nov., as Salibacillus salexigens comb. nov. Int J Syst Bacteriol 49, 821-831.

Wayne, L. G., Brenner, D. J., Colwell, R. R., Grimont, P. A. D., Kandler, O., Krichevsky, M. I., Moore, L. H., Moore, W. E. C., Murray, R. G. E. \& other authors (1987). International Committee on Systematic Bacteriology. Report of the ad hoc committee on reconciliation of approaches to bacterial systematics. Int J Syst Bacteriol 37, 463-464.

Wieser, M., Worliczek, H., Kämpfer, P. \& Busse, H.-J. (2005). Bacillus herbersteinensis sp. nov. Int J Syst Evol Microbiol 55, 2119-2123.

Wu, C., Lu, X., Qin, M., Wang, Y. \& Ruan, J. (1989). Analysis of menaquinone compound in microbial cells by HPLC. Microbiology [English translation of Microbiology (Beijing)] 16, 176-178.

Xue, Y., Ventosa, A., Wang, X., Ren, P., Zhou, P. \& Ma, Y. (2008). Bacillus aidingensis sp. nov., a moderately halophilic bacterium isolated from Ai-Ding salt lake in China. Int J Syst Evol Microbiol 58, 2828-2832.

Yoon, J.-H., Weiss, N., Lee, K.-C., Lee, I.-S., Kang, K.-H. \& Park, Y.-H. (2001). Jeotgalibacillus alimentarius gen. nov., sp. nov., a novel bacterium isolated from jeotgal with L-lysine in the cell wall, and reclassification of Bacillus marinus Rüger 1983 as Marinibacillus marinus gen. nov., comb. nov. Int J Syst Evol Microbiol 51, 2087-2093.

Yoon, J.-H., Kim, I.-G., Kang, K.-H., Oh, T.-K. \& Park, Y.-H. (2004). Bacillus hwajinpoensis sp. nov. and an unnamed Bacillus genomospecies, novel members of Bacillus rRNA group 6 isolated from sea water of the East Sea and the Yellow Sea in Korea. Int J Syst Evol Microbiol 54, 803-808.

Zhang, J., Zhang, Y., Xiao, C., Liu, Z. \& Goodfellow, M. (2002). Rhodococcus maanshanensis sp. nov., a novel actinomycete from soil. Int J Syst Evol Microbiol 52, 2121-2126.

Zhang, J., Wu, D., Zhang, J., Liu, Z. \& Song, F. (2008). Saccharopolyspora shandongensis sp. nov., isolated from wheat-field soil. Int J Syst Evol Microbiol 58, 1094-1099.

Zhang, J., Song, F., Xin, Y.-H., Zhang, J. \& Fang, C. (2009). Microvirga guangxiensis sp. nov., a novel alphaproteobacterium from soil, and emended description of the genus Microvirga. Int J Syst Evol Microbiol 59, 1997-2001.

Zhou, Y., Wei, W., Chen, Q., Xu, Y., Wang, X., Huang, X. \& Lai, R. (2008). Bacillus pallidus sp. nov., isolated from forest soil. Int J Syst Evol Microbiol 58, 2850-2854.

Zhou, Y., Xu, J., Xu, L. \& Tindall, B. J. (2009). Falsibacillus pallidus to replace the homonym Bacillus pallidus Zhou et al. 2008. Int J Syst Evol Microbiol 59, 3176-3180. 